\title{
Malnutrition Research Output: A Bibliometric Analysis for articles Index in Web of Science between 1900 and 2020
}

\author{
Taha Hussein Musa ${ }^{1,2,3 * \dagger}$, Tosin Yinka Akintunde ${ }^{3,4,5^{* *}}$, Hassan Hussein Musa ${ }^{3,6}$, Upama Ghimire ${ }^{7}$, Ghislaine Gatasi ${ }^{3,7}$ \\ ${ }^{1}$ Key Laboratory of Environmental Medicine Engineering, Ministry of Education; Department of Epidemiology and Health Statistics, School of Public Health, Southeast \\ University, Nanjing (210009), CHINA \\ ${ }^{2}$ Biomedical Research Institute, Darfur University College, Nyala, SUDAN \\ ${ }^{3}$ Organization of African Academic Doctor (OAAD), Off Kamiti Road, P.OBox 25305000100, Nairobi, KENYA \\ ${ }^{4}$ Department of Sociology, School of Public Administration, Hohai University, Nanjing, CHINA \\ Department of Demography and Social Statistics, Obafemi Awolowo University, Osun State, NIGERIA \\ ${ }^{6}$ Department of Medical Microbiology, Faculty of Medical Laboratory Sciences, University of Khartoum, Khartoum, SUDAN \\ Key Laboratory of Environmental Medicine Engineering, Department of Epidemiology and Health Statistics, School of Public Health, Southeast University, Nanjing, \\ 10009, Jiangsu Province, CHINA \\ $t$ : These authors contributed equally to this article \\ *Corresponding Author: taha.hm99@yahoo.com \\ ${ }^{\star \star}$ Corresponding Author: akintunde.ty@hhu.edu.cn
}

Citation: Musa TH, Akintunde TY, Musa HH, Ghimire U, Gatasi G. Malnutrition Research Output: A Bibliometric Analysis for articles Index in Web of Science between 1900 and 2020. Electron J Gen Med. 2021;18(3):em293. https://doi.org/10.29333/ejgm/10840

ARTICLE INFO

Received: 12 Feb. 2021

Accepted: 7 Apr. 2021

\begin{abstract}
Introduction: Malnutrition is a significant cause of child morbidity and mortality, and it remains a global health issue with high prevalence. Here, we carried out a bibliometric survey to provide global scientific research output on malnutrition and identify the research gaps and future research direction from published papers searched in Web of Science (WoS).
\end{abstract}

Methods: A comprehensive analysis was generated by searching the WoS database. Medical Subject Headings (MeSH), was used to search terms 'Malnutrition' or 'Malnourishment' or 'Nutritional Deficiency' or 'Undernutrition' or 'Nutrition Disorders.' Was used to retrieve article published in between 1900 and 2020. Only original research and review papers published in English were included in the analysis. SPSS, HistCite, Bibliometrix app." (Using R), and VOSviewer ver 1.6.6 were used for analysis.

Results: Research output peak from 1972 to 2007 with 100(0.99\%) articles, in 2008 to 2012 with more than 200 $(1.98 \%)$ articles, while the year 2019 and 2020 had the least more than 500 (4.95\%) articles per year. The United States ranked first in terms of the number of articles 1947(19.28\%), followed by United Kingdom 604 (5.98\%), and Brazil $412(4.08 \%)$. In addition, our analyses revealed a significant correlation between the total number of citations Year science publications $(r=0.9216, p<0.0001)$, and between number of countries $(r=0.9219, p<0.0001)$, and number of Number of authors $(r=0.4149, p<0.0001)$, and Institution $(r=0.5534, p<0.0001)$, Journal $h \_i n d e x$ $(r=0.6927, p<0.0001)$, and Journal impact factors $(r=0.6364, p<0.0544)$.

Conclusion: This bibliometric analysis provides insights into the global overview on the annual trend of the global malnutrition research output, institution, journal, authors, and countries.

Keywords: malnutrition, global research, Web of Science, bibliometric analysis, vOSviewer, HistCite

\section{INTRODUCTION}

Malnutrition over the last century has been a worrisome morbidity condition that remains a disease burden globally [1] and subsequently drained global economic resources [2]. However, there has been concerted effort to ensure that people of all ages are less vulnerable to the intricacy of malnutrition [3] through researches and investment programs from governments, NGOs, and private entities. With these efforts, the developed countries have witnessed massive progress in combating malnutrition that was equally diffused into the developing countries. This progress is measured in terms of reduced child mortality attributed to low malnutrition prevalence, longer life expectancy for the aging population, and improved maternal health services. The persisting malnutrition situation in developing countries negates these achievements as malnutrition is a global problem that requires international policies and research [4].

In recent years, maternal and child malnutrition attention has shifted to the population in developing countries. Some of the focal points for research are evidenced in the problem of overweight and obesity. The incidence of maternal overweight and obesity has steadily increased since early 1980 and exceeds underweight in all world regions [5]. It has since been reported that lower birth weight and undernutrition were risk factors for high glucose concentrations and increased blood pressure rate [6].

Similarly, malnutrition which includes undernutrition (wasting, stunting, underweight), inadequate vitamins or 
minerals, overweight, obesity, and resulting in diet-related non-communicable diseases, is a complex problem that affects people in every country. Approximately 52 million of the children under-fives are suffering from wasting, 462 million are underweight, and 1.9 billion adults worldwide are overweight or obese. And it continues to affect the lives of millions of children and women worldwide [7-12] which is associated with many socioeconomic factors [13]. Therefore, the effort to solve malnutrition spurred rapid progress with several recent advances and research productivity to combat high mortality and disease burden $[14,15]$.

Furthermore, malnutrition feast on the population with underlying health conditions and subsequently distorts medical treatments' progress. In specific, people with renal conditions [16-18], geriatric population [19,20], hospital patients [21], and cancer patients [22] are some of the most susceptible in the global community. While this means research on methods and approaches to combating malnutrition must continue, it is crucial to adjudicate trends and progress of research on malnutrition globally.

Like in review articles [23-25], the utilization of Bibliometrics Analysis, a tool and technique widely used by many researchers worldwide $[26,27]$, presents a cumulative understanding of malnutrition eradication effort. The analytical approach of annual trends of publication, institutions, journals, authors, country and international collaboration networks, citations, keywords occurrence, and contributed funding agency can help researchers and decisionmakers gain insight into the research productivity to understand scientific research progress in malnutrition-related publications better.

Therefore, the study aimed to assess the global research output focusing on malnutrition research and identify the most influential factors associated with the citations and further identify the research gaps and future study direction.

\section{MATERIAL AND METHODS}

\section{Data Sources}

Published peer-reviewed articles on malnutrition were retrieved from the Web of Science (WoS) database (https://apps.webofknowledge.com/) through a comprehensive online search of documents published between the years 1900-2020.

\section{Search Strategy}

All the malnutrition-related publications from WoS were collected on a single day (on 20 February 2021) by two researchers (THM \& HHM) to avoid the WoS database update. $A$ comprehensive search was conducted by using Medical Subject Headings (MeSH), which is available on (https://meshb.nlm.nih.gov/search). The following terms searched as follows: Title: Malnutrition*" OR "undernutrition" OR "Nutrition Deficiency" OR "Nutrition disorders" OR "malnourishment" Timespan: All years (1900-2020), and documents Indexes: Science Citation Index Expanded (SClEXPANDED) and Social Sciences Citation Index (SSCI). The search was restricted to only "article" and "review, and for documents only written in English regarding document types. Finally, the resulting bib.txt data was downloaded from WoS, and as a result, 10100 documents related to malnutrition were
Table 1. Main Information about data on malnutrition

\begin{tabular}{|c|c|}
\hline Description & Results \\
\hline Timespan & 1905:2020 \\
\hline Sources (Journals, Books, etc) & 2033 \\
\hline Documents & 10100 \\
\hline Total citations of the documents & 263742 \\
\hline Average years from publication & 23.3 \\
\hline Average citations per documents & 26.11 \\
\hline Average citations per year per doc & 1.7 \\
\hline References & 203413 \\
\hline \multicolumn{2}{|l|}{ Document types } \\
\hline Article & $9307(92.15 \%$ \\
\hline Review & $793(7.85 \%)$ \\
\hline \multicolumn{2}{|l|}{ Document contents } \\
\hline Keywords Plus & 10028 \\
\hline Author's Keywords & 9447 \\
\hline \multicolumn{2}{|l|}{ Authors } \\
\hline Authors & 31003 \\
\hline Author Appearances & 46501 \\
\hline Authors of single-authored documents & 1045 \\
\hline Authors of multi-authored documents & 29958 \\
\hline \multicolumn{2}{|l|}{ Authors collaboration } \\
\hline Single-authored documents & 1459 \\
\hline Documents per Author & 0.326 \\
\hline Authors per Document & 3.07 \\
\hline Co-Authors per Documents & 4.6 \\
\hline Collaboration Index & 3.47 \\
\hline
\end{tabular}

the subject of further analysis. To account for variations in the publications, the Growth Demand Production (GDP) for each country were retrieved from the website https://data.worldbank.org/indicator/NY.GDP.MKTP.CD.

\section{Ethical consideration}

There is no formally constituted research ethics required for this study since all data were open sources and do not involve human or animal subjects.

\section{Bibliometric Indicators and Mapping Visualizations}

The following data were extracted from the retrieved publications: title, year of publication, author details, country, institution, journal, and citation number. This method was used to evaluate citation density (i.e., an average of the number of citations received per year and per article), the annual trend of publications, most productive authors, institutions and journals, and country contributions. The study's quality of publications was assessed using the Hirsh-index (h-index) [28]. The impact factor (IF) for the year 2019 was presented for the top 10 journals reported.

\section{Data Analysis}

Network analysis of co-authorship was also analyzed and visualized using voSviewer software [29]. Bibliometrics (an R package) [30], GraphPad Prism 5 [31] were used for frequency analysis and data visualization. Correlation Coefficient between the variable were conducted to assess the relationship between variables. A P-value less than 0.05 was considered statistically significant.

\section{General Characteristics of study}

Table 1 shows the various types of retrieved documents information. A total of 2033 journals, 31003 Authors, and with Collaboration Index 3.48 were contributed to produce 10100 studies on Malnutrition-related publications. Among the total 


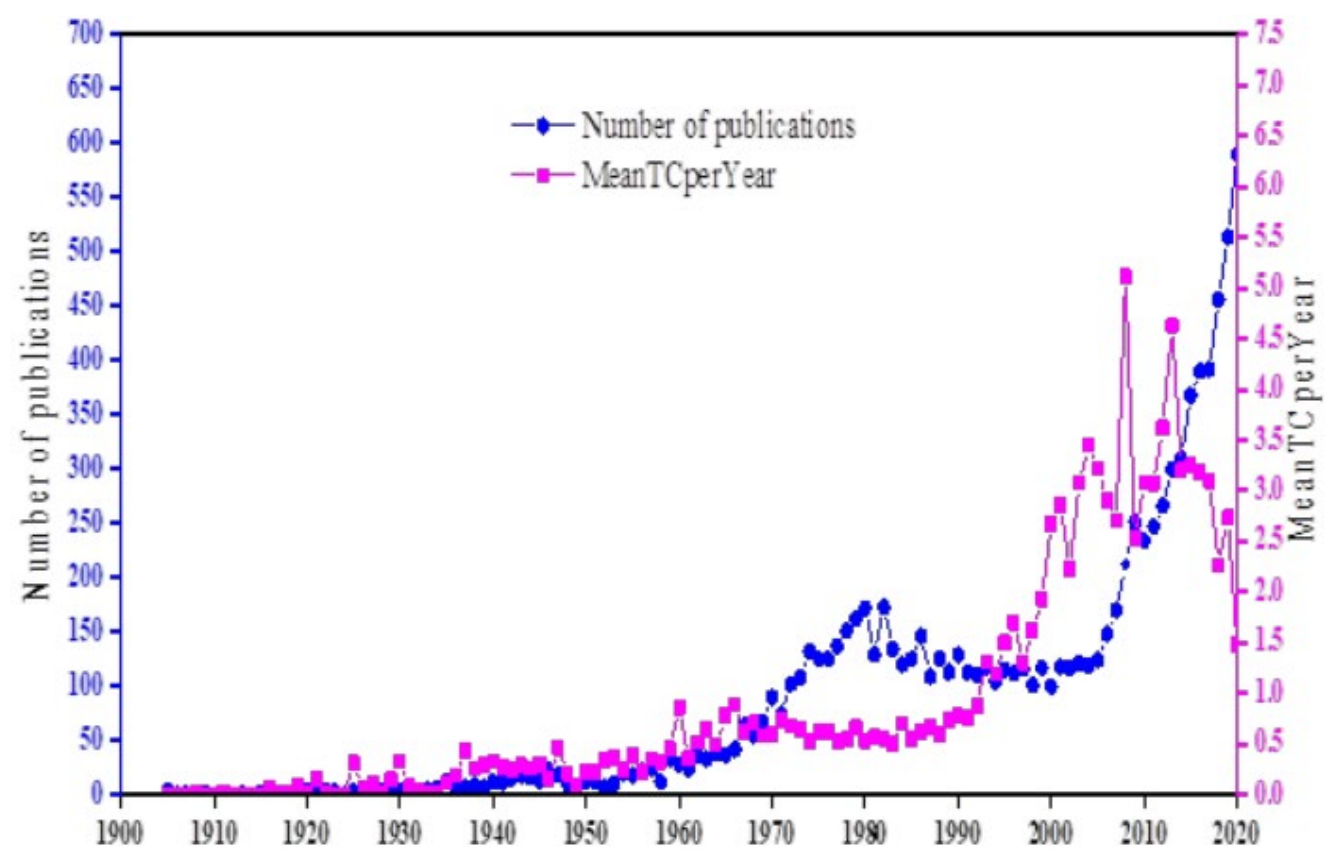

Figure 1. Global publication and citation trend in Malnutrition-related publications

Table 2. Top 10 highly cited articles in malnutrition

\begin{tabular}{|c|c|c|c|c|}
\hline SCR & Date Author / Journal & TC & $\mathrm{TC} / \mathrm{t}$ & TD \\
\hline 1 & $\begin{array}{l}\text { Black RE, et al. Maternal and child undernutrition 1-Maternal and child undernutrition: global and } \\
\text { regional exposures and health consequences. Lancet. } 2008 \text { JAN 19;371(9608):243-260 }\end{array}$ & 2890 & 206.43 & Review \\
\hline 2 & $\begin{array}{l}\text { Black RE, et al. Maternal and child undernutrition and overweight in low-income and middle-income } \\
\text { countries. Lancet. } 2013 \text { Aug 3; } 382 \text { (9890):427-451 }\end{array}$ & 2851 & 316.78 & Review \\
\hline 3 & $\begin{array}{l}\text { Victora CG, et al. Maternal and child undernutrition 2-Maternal and child undernutrition: consequences } \\
\text { for adult health and human capital. Lancet. } 2008 \text { Jan-Feb; 371(9609): 340-357 }\end{array}$ & 1706 & 121.86 & Review \\
\hline 4 & $\begin{array}{l}\text { Stenvinkel P, et al. Strong association between malnutrition, inflammation, and atherosclerosis in } \\
\text { chronic renal failure. Kidney International. } 1999 \text { May; } 55 \text { (5): 1899-1911 }\end{array}$ & 1274 & 55.39 & $\begin{array}{l}\text { Comparative } \\
\text { Study }\end{array}$ \\
\hline 5 & $\begin{array}{c}\text { Bhutta ZA, et al. Maternal and Child Undernutrition } 3 \text { - What works? Interventions for maternal and child } \\
\text { undernutrition and survival. Lancet. } 2008 \text { Feb } 2 ; 371(9610): 417-440\end{array}$ & 1181 & 84.36 & Review \\
\hline 6 & $\begin{array}{l}\text { Winick M, Noble A. Cellular response in rats during malnutrition at various ages. Journal of Nutrition. } \\
\qquad 1966 ; 893: 300-\&\end{array}$ & 966 & 17.25 & Review \\
\hline 7 & $\begin{array}{l}\text { Correia MITD, Waitzberg DL. The impact of malnutrition on morbidity, mortality, length of hospital stay } \\
\text { and costs evaluated through a multivariate model analysis. Clinical Nutrition. } 2003 \text { Jun; } 22 \text { (3): 235-239 }\end{array}$ & 937 & 49.32 & Article \\
\hline 8 & $\begin{array}{l}\text { Rubenstein LZ, et al. Screening for undernutrition in geriatric practice: Developing the Short-Form Mini- } \\
\text { Nutritional Assessment (MNA-SF). Journals of gerontology series A-biological Sciences and Medical } \\
\text { Sciences. } 2001 \text { Jun; } 56 \text { (6): M366-M372 }\end{array}$ & 888 & 42.29 & Article \\
\hline 9 & $\begin{array}{l}\text { Mcwhirter JP, Pennington CR. Incidence and Recognition of malnutrition IN-Hospital. British Medical } \\
\text { JournaL. } 1994 \text { Apr 9; } 308 \text { (6934): 945-948 }\end{array}$ & 872 & 31.14 & Articles \\
\hline 10 & $\begin{array}{l}\text { Bistrian BR, et al. prevalence of malnutrition in general medical patients. JAMA-Journal of the American } \\
\text { Medical Association. 1976; } 235 \text { (15): 1567-1570 }\end{array}$ & 746 & 16.22 & Article \\
\hline
\end{tabular}

SCR: Standard competition ranking, TC: Total number of citations, TC/t: Average of Total ciations per year, TD: type of documents

number, 9307 (92.15\%) were research articles, and 793 (7.85\%) are review papers.

\section{Annual Trend of the Publications}

Figure 1 shows the number of retrieved articles in Malnutrition-related publications per year along with their average mean of score. The number of articles increased by 100 between 1972 to 2007 and more than 200 articles in 2008 to 2012, while those published in the year 2019 and 2020 had more than 500 articles per year.

\section{Top 10 Highly Cited Articles in Malnutrition}

The top 10 highly cited articles on in malnutrition-related publications were presented in Table 2 [5,6,14,16,19,32-36]. Of the top 10 list, 5 were review articles, 4 research articles, and a comparative study. The article which received the highest number of citations was "Maternal and child undernutrition 1Maternal and child undernutrition: global and regional exposures and health consequences" published by Black RE et al. (2008) with obtained 2890 citations [14], followed by "Maternal and child undernutrition and overweight in lowincome and middle-income countries" published by Black RE et al. (2013) with obtained 2851 [5].

\section{Authors Productivity}

The top 10 active authors also showed that four authors were from the USA, and only one author from Kenya, one from Bangladesh, two from England, and two from Copenhagen, Denmark. Similarly, Galler JR from Harvard Medical School, Dept Psychiat, Boston, USA was the most influential authors with produced 86 articles, with h_index 29 and total citations score 3122 times, followed by Briend A from University of 
Table 3. Top 10 productive authors in malnutrition

\begin{tabular}{|c|c|c|c|c|c|c|}
\hline Author & University & h_index & g_index & TC & NP & PY_start \\
\hline Galler, J.R. & Harvard Medical School, Department of Psychiat, Boston, USA & 29 & 53 & 3122 & 86 & $1977 \sim 2020$ \\
\hline Briend, $\mathrm{A}$. & University of Copenhagen, Fac Sci, Frederiksberg, Denmark & 15 & 31 & 991 & 47 & 1979 2020 \\
\hline Ahmed, T. & $\begin{array}{c}\text { International Centre for Diarrhoeal Disease Research (ICDDR), Nutr \& } \\
\text { Clin Serv Div } \\
\text { Dhaka, Bangladesh }\end{array}$ & 16 & 44 & 2097 & 44 & $2007 \sim 2020$ \\
\hline Kerac, M. & University of London, London Sch Hyg \& Trop Med, London, England & 15 & 25 & 697 & 40 & $2008 \sim 2020$ \\
\hline Berkley, J.A. & KEMRI Wellcome Trust Research Programme, Kenya & 16 & 29 & 887 & 38 & $2006 \sim 2020$ \\
\hline Friis, $\mathrm{H}$. & $\begin{array}{l}\text { University of Copenhagen, Departments of nutrtional Exercise \& } \\
\text { Sports Copenhagen, Denmark }\end{array}$ & 11 & 20 & 455 & 37 & $2002 \sim 2020$ \\
\hline Tonkiss, J. & Boston University, Boston, USA & 22 & 37 & 1664 & 37 & $1983 \sim 2011$ \\
\hline Morgane, P.J. & University of New England -Maine, Dept Biomed Sci, BIddeford, USA & 22 & 36 & 2074 & 36 & $1974 \sim 2019$ \\
\hline Manary, M.J. & Washington University, Dept Pediat, USA & 17 & 31 & 964 & 34 & $1997 \sim 2020$ \\
\hline Mccance R.A. & King's College Hospital NHS Foundation Trust, London, England & 21 & 34 & 1422 & 34 & $1953 \sim 1969$ \\
\hline
\end{tabular}

TC: Total number of citations, NP: Number of articles

Table 4. Top 10 productive and influential countries in malnutrition

\begin{tabular}{|c|c|c|c|c|c|c|c|c|c|}
\hline Country $(\mathrm{N}=119)$ & NP & $(\%)$ & GDP (US\$) & NP per GDP & TC & SCP & (\%) & MCP & $(\%)$ \\
\hline USA & 1947 & 19.28 & 97.799 & 101 & 71519 & 1500 & 14.85 & 447 & 4.43 \\
\hline United Kingdom & 604 & 5.98 & 2.829 & 214 & 20715 & 424 & 4.20 & 180 & 1.78 \\
\hline Brazil & 437 & 4.33 & 1.84 & 238 & 10152 & 379 & 3.75 & 58 & 0.57 \\
\hline India & 412 & 4.08 & 2.869 & 144 & 4530 & 373 & 3.69 & 39 & 0.39 \\
\hline Australia & 283 & 2.80 & 1.397 & 203 & 8158 & 203 & 2.01 & 80 & 0.79 \\
\hline France & 273 & 2.70 & 2.716 & 101 & 8484 & 186 & 1.84 & 87 & 0.86 \\
\hline China & 255 & 2.52 & 14.343 & 18 & 2877 & 200 & 1.98 & 55 & 0.54 \\
\hline Canada & 239 & 2.37 & 1.736 & 138 & 5994 & 162 & 1.60 & 77 & 0.76 \\
\hline Japan & 237 & 2.35 & 5.082 & 47 & 3503 & 208 & 2.06 & 29 & 0.29 \\
\hline Spain & 196 & 1.94 & 1.393 & 141 & 3850 & 155 & 1.53 & 41 & 0.41 \\
\hline
\end{tabular}

NP: Number of articles, GDP: Gross Domestic Product, TC: Total citations, SCP: Single country Publications, MCP: Multiple country publications

Table 5. Top 10 journal contributes in malnutrition

\begin{tabular}{|c|c|c|c|c|c|c|}
\hline Source & h_index & TC & NP & IF (2019) & 5 year rank & Journal rank \\
\hline American Journal of Clinical Nutrition & 63 & 14458 & 341 & 6.77 & 7.831 & Q1 \\
\hline British Journal of Nutrition & 45 & 6550 & 214 & 3.334 & 4.284 & Q1 \\
\hline Journal of Nutrition & 48 & 7866 & 190 & 4.281 & 5.075 & Q1 \\
\hline Clinical Nutrition & 52 & 10193 & 187 & 6.36 & 6.28 & Q1 \\
\hline Plos One & 28 & 2590 & 176 & 2.74 & 3.227 & Q2 \\
\hline Nutrition & 39 & 5805 & 166 & 3.639 & 4.118 & Q2 \\
\hline European Journal of Clinical Nutrition & 29 & 2666 & 113 & 3.291 & 3.447 & Q2 \\
\hline Nutrition Reviews & 21 & 1641 & 113 & 6.50 & 7.617 & Q1 \\
\hline Journal of Tropical Pediatrics & 18 & 1140 & 109 & 0.94 & 1.239 & Q4 \\
\hline Journal of Parenteral and Enteral Nutrition & 30 & 3917 & 104 & 2.853 & 3.881 & Q3 \\
\hline
\end{tabular}

TC: Total citations, NP: Number of articles

Copenhagen, Fac Sci, Frederiksberg, Denmark with published 47 articles and received $\mathrm{h}$-index 15 and total citations 991 times (Table 3).

\section{Top 10 Productive Countries}

A total of 119 countries contributed to publishing articles on malnutrition. Table 4 shows the top 10 active and influential countries in publishing malnutrition-related documents. The top 10 active countries participated in publishing a total of $4883(48.35 \%)$. The United States of America (USA) (1947; $19.28 \%$ ) had the most outstanding share of publications in malnutrition, followed by the United Kingdom (UK) (604; $5.98 \%)$, Brazil (437; 4.33\%), and India (412, 4.33\%). Other countries such as Australia, France, China, Canada, Japan, and Spain were leading countries for research during the study period and were also listed within the top 10 productive and active countries. There is a significant correlation between the number of articles and total citation score $(r=0.990, P<0.0001)$, followed by the number of articles and MCP $(r=0.997,<0.0001)$, and $\operatorname{SCP}(r=0.874, \mathrm{P}<0.0001)$.
The top 10 journal contributes in Malnutrition-related publications are presented in Table 5. American Journal of Clinical Nutrition with h_index (63) is the top active journal, followed by the British Journal of Nutrition h_index (54), Clinical Nutrition with $\mathrm{h} \_$index (52), and Journal of Nutrition with h_index (48).

The most frequency of Keywords Plus. The top 25 indexed Mesh Keyword Plus are "nutritional-status" (905), followed by "mortality" (761), "nutrition" (644), "prevalence" (587), and "Children" (576), "impact" (340), "disease" (314), "risk-factor" (237), "care" (235), "management" (223), "Body mass index" (218), "subjective global assessment" (182), "weight-loss" (180), "malnourished children" (172), "outcomes" (172), "association" (171), "metabolism" (165), and "expression" (164).

Figure 3 shows the common conceptual frameworks in retrieved articles on malnutrition-related publications determined by using the Factorial Analysis and Corresponding Analysis method, with five clusters of $1,7,6,7$, and 79 elements showed research responses focused on "gene-expression", 


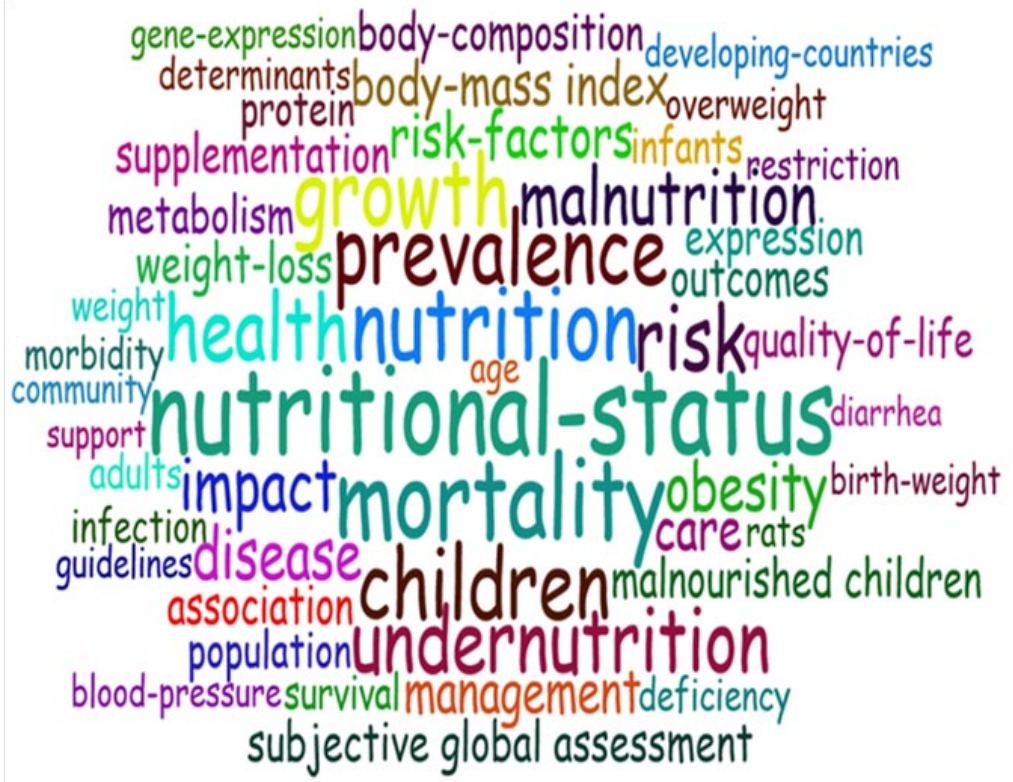

Figure 2. WordCloud of Keywords Plus in Malnutrition

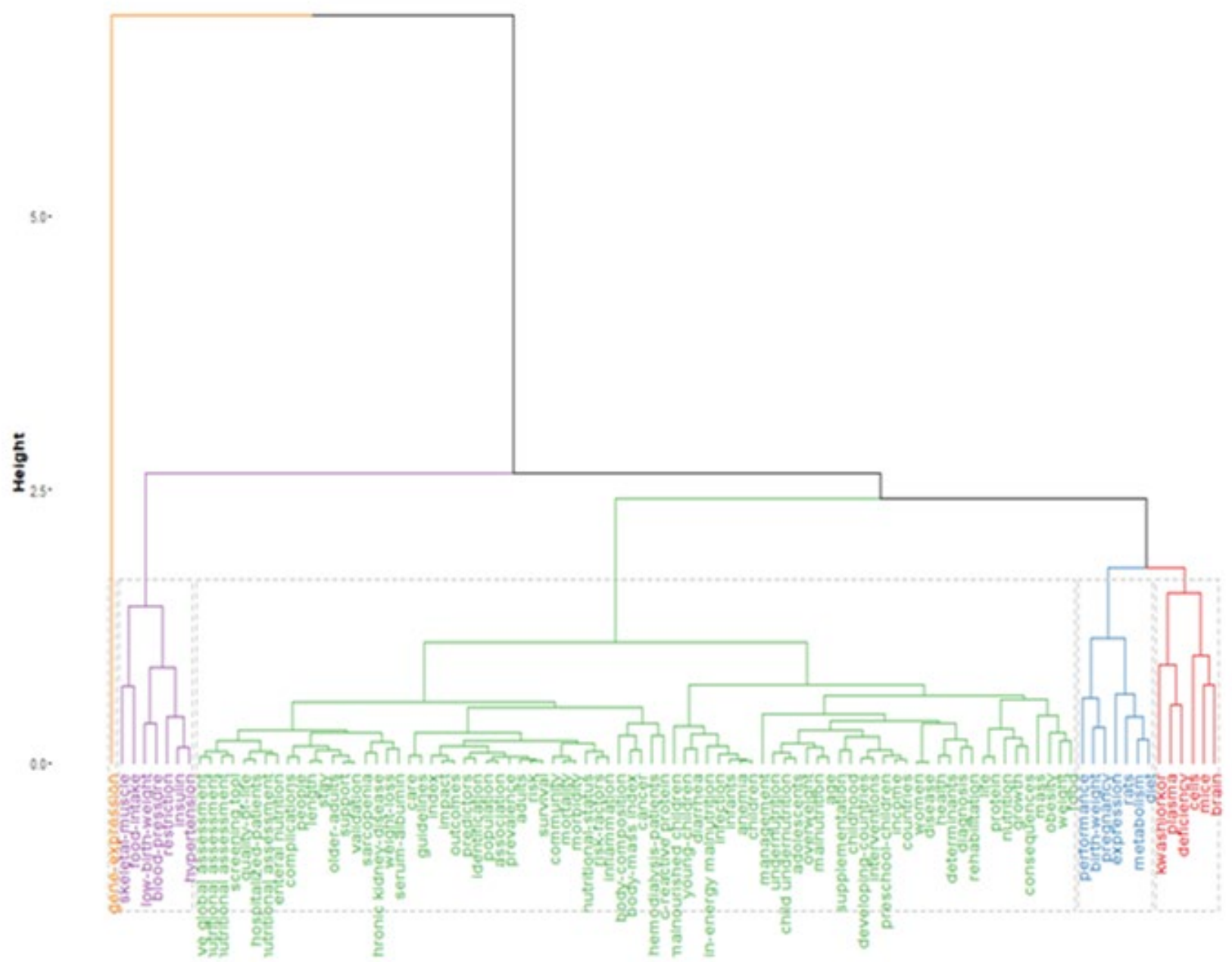

Figure 3. Analysis of common conceptual frameworks associated with malnutrition studies by using the Corresponding analysis method. The 100 terms of retrieved articles clustering within five clusters of sizes 1,7,6, 7 and 79 reflecting concepts frequently linked to malnutrition

followed by "skeletal-muscle, food intake, low-birthweight, blood pressure, insulin, and hypertension", and others.
Based on a threshold of where only the authors with at least five documents are displayed in Figure $\mathbf{4}$ and each circle, the size of a circle represents an author, quantity of publications, and co-authorship strengths. A total of 741 authors clustered 


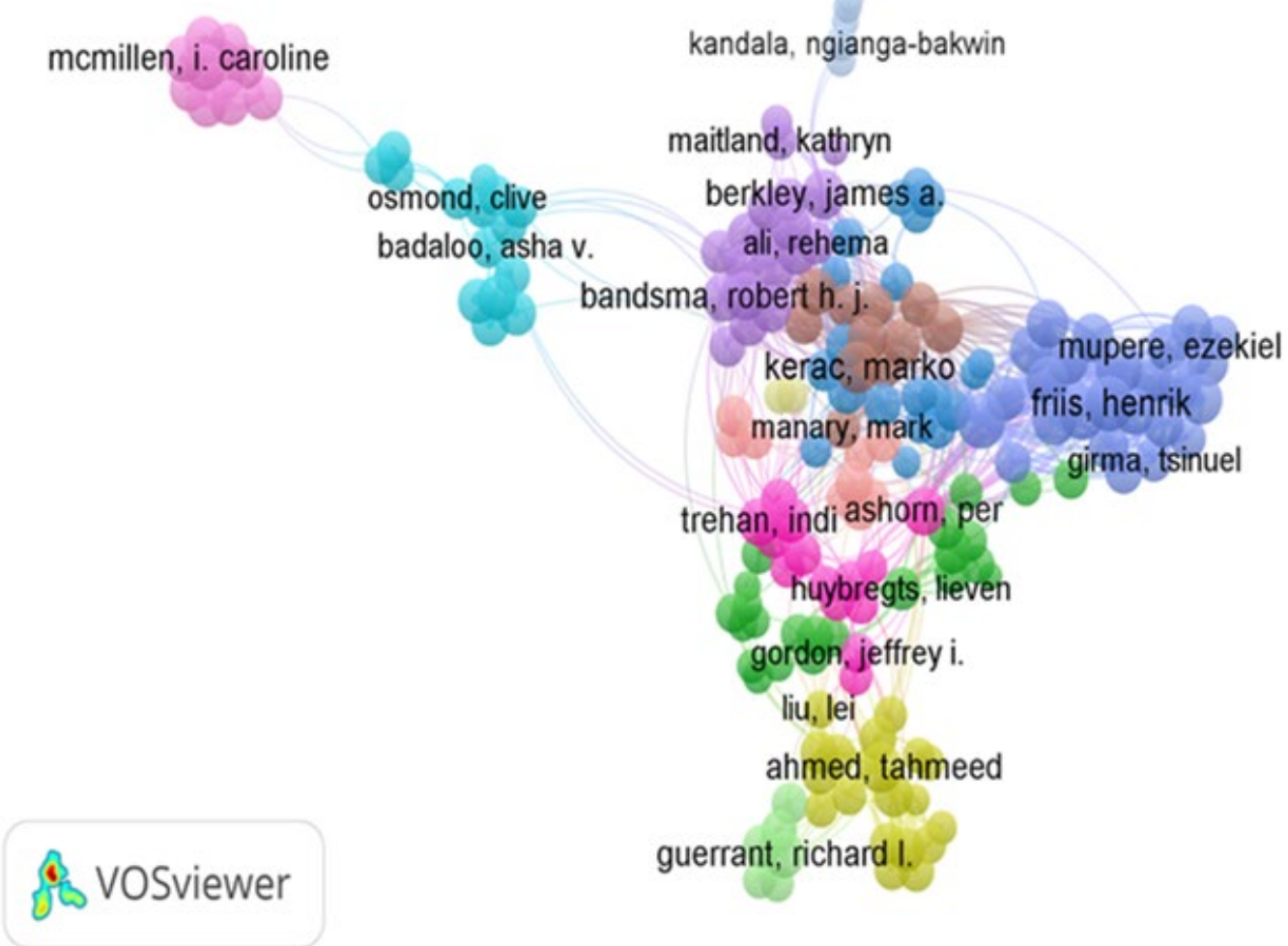

Figure 4. Co-authorship network among productive Authors

Table 6. Top 10 active institution and research area in malnutrition

\begin{tabular}{|c|c|c|c|c|c|}
\hline \multicolumn{3}{|l|}{ Organizations Enhanced research } & \multicolumn{3}{|l|}{ Research Areas } \\
\hline Organizations & NP & $(\%)$ & Research area & NP & $(\%)$ \\
\hline University of London & 404 & 4.000 & Nutrition dietetics & 2,966 & 29.366 \\
\hline Harvard university & 239 & 2.366 & Pediatrics & 1,083 & 10.723 \\
\hline University of California System & 203 & 2.010 & general internal medicine & 912 & 9.030 \\
\hline University College London & 175 & 1.733 & Public Environmental Occupational Health & 868 & 8.594 \\
\hline London school of Hygiene tropical medicine & 168 & 1.663 & Neurosciences Neurology & 573 & 5.673 \\
\hline Universidade de sao paulo & 149 & 1.475 & Endocrinology Metabolism & 432 & 4.277 \\
\hline $\begin{array}{l}\text { Institute national de la sante et de la recherché } \\
\text { Medicale inserm }\end{array}$ & 139 & 1.376 & Research Experimental Medicine & 342 & 3.386 \\
\hline Johns Hopkins university & 139 & 1.376 & Tropical Medicine & 337 & 3.337 \\
\hline University of Toronto & 114 & 1.129 & Science Technology other topics & 313 & 3.099 \\
\hline Cornell university & 107 & 1.059 & Geriatrics Gerontology & 309 & 3.059 \\
\hline
\end{tabular}

NP: Number of articles

together in thirteen distinct groups (TLS $=2857$ ). Also, our results revealed that Friis, Henrik ( $T L S=217)$, Kerac, Marko (TLS=130), Berkley, Marko (130), Trehan, Indi (TLS=65), Guerrant, Richard I. (TLS=48).

\section{Organizations and Research Area in Malnutrition}

The table revealed the top 10 organizations and research areas that enhanced research on malnutrition. The most productive Organizations were the University of London (404, $4.00 \%$ ), followed by Harvard University (239, 2.366\%), the University of California System (203, 2.010\%) of Malnutrition articles, and the University College London (175; 1.733\%) of Malnutrition articles. The top research area on Malnutrition is Nutrition dietetics $(2,966,29.366 \%)$, followed by Pediatrics (1,083, 10.723\%), and General Internal Medicine (912, 9.03\%), and Public Environmental Occupational Health (868, 8.594\%), were most of the top research area (Table 6).
Table 7 shows that the most funding is come from the United States Department of Health Human Services $678(6.71 \%)$, followed by National Institutes of Health (NIH) USA 669(6.62\%), and NIH Eunice Kennedy Shriver National Institute of Child Health Human Development 207 (2.05\%), respectively.

\section{Factors Affecting the Number of Citations}

The comprehensive investigation of possible factors influencing citations in malnutrition research articles was presented in Table 8. The significant correlations were found between the number of citations and Year science publications $(r=0.9216, P<0.0001)$, number of countries $(r=0.9219, P<0.0001)$, and number of Number of authors $(r=0.4149, P<0.0001)$, and Institution ( $r=0.5534, P<0.0001)$, Journal $h \_$index $(r=0.6927$, $P<0.0001)$, and Journal impact factors $(r=0.6364, P<0.0544)$. 
Table 7. Top 10 funding Agencies on Malnutrition-related publications

\begin{tabular}{|c|c|c|}
\hline Record Count & NP & $(\%)$ \\
\hline United States Department of Health Human Services & 678 & 6.71 \\
\hline National Institutes of Health NIH USA & 669 & 6.62 \\
\hline NIH Eunice Kennedy Shriver National Institute of Child Health Human Development & 207 & 2.05 \\
\hline NIH National Institute of Diabetes Digestive Kidney Diseases Niddk & 151 & 1.49 \\
\hline Wellcome trust & 113 & 1.11 \\
\hline National Council for Scientific and Technological Development & 111 & 1.09 \\
\hline Nih National Institute of Allergy Infectious Diseases & 104 & 1.03 \\
\hline UK Research Innovation UKRI & 102 & 1.01 \\
\hline Medical Research Council UK MRC & 80 & 0.79 \\
\hline Bill Melinda Gates Foundation & 76 & 0.75 \\
\hline
\end{tabular}

Table 8. Factors affecting the number of citations in malnutrition articles

\begin{tabular}{ccc}
\hline Factor & Spearman's r & P value \\
\hline Year science publications & 0.9216 & $<0.0001$ \\
\hline Number of authors & 0.4149 & $<0.0001$ \\
\hline Journal h_index & 0.6927 & $<0.0001$ \\
\hline Journal impact factors (2019) & 0.6364 & 0.05219 \\
\hline Number of countries & 0.5534 & $<0.0001$ \\
\hline Institution & $<0.0001$ & \\
\hline
\end{tabular}

\section{DISCUSSION}

This study is the first to examine the bibliometric analysis of global research on malnutrition to the authors' knowledge. The current research findings elucidate the extent to which researchers have made efforts to curb malnutrition globally. The bibliometric analysis output offers a robust insight into publications and empirical evidence of global malnutritionrelated problems in the WoS. Based on the research finding, over 116 years, there have been 10,100 studies on malnutrition with an estimation of $92 \%$ original research articles and $8 \%$ review articles. There was a notable rise in research on malnutrition-related topics five years after the year 2000. This sharp rise may be attributed to the global policy framework baseline date on the Millennium Development Goals (MDGs) [37]. The MDGs ushered in strong interest from researchers to explore result-centered investigations and risk factors for malnutrition, including the most vulnerable groups. Subsequently, there was corroborative evidence on reduced malnutrition on a global scale [38-40]. Similarly, the introduction of the sustainable development goals (SDGs) [41] ensured continued effort to maintain MDGs achievement. Subsequently, research output in the WoS stays on the upward swing.

The retrospective observation of citation for top scientific evidence on malnutrition shows the three most cited articles were on maternal and child malnutrition deficiencies. Other top citations were from research on prominent vulnerable groups: those with kidney ailments, the aging population, and general medical patients. The first three were review article that presents an aggregation of research evidence on maternal and child undernutrition while focusing on the global and regional exposure, overweight in low and middle-income countries and the health consequences. Although these results show that more attention has been placed on maternal and child malnutrition-related issues, it also suggests that these groups are the most susceptible to malnutrition globally. This assertion is consistent with the micro bibliometric study of health and medical research in Nepal [42] that found child and maternal malnutrition as leading health research and bibliometric evidence comparing malnutrition research in academia against social media [43].

Other prominently cited articles bordering on renal issues, aging groups, and hospital patients create a paradigm for addressing the population vulnerable to malnutrition. Over the years, the aging population and their vulnerability to malnutrition have gained extensive attention, and there has been increased number of research in Saudi Arabia [44]. Similarly, renal citations have equally gained research prominence [45].

Beyond the most cited research publications, some of the most prominent authorship and institution were from the United States, England, and Denmark. While recent evidence has identified that most recent global malnutrition cases are prevalent in developing countries $[46,47]$, only Kenya and Bangladesh were among the top authors globally. This exposition suggests a significant dearth of authorship coming from the developing countries represented in the web of science databases. If there were authorship, they lack global exposure that could facilitate immediate, worldwide distribution and accessible empirical evidence on malnutrition-related problems. However, the leading authorship position coming from the United States and Europe should be acknowledged, as they remain instrumental in facilitating the eradication of the global problem of malnutrition.

Our keyword analysis also demonstrated that the most common keywords included were nutritional statuses, mortality, nutrition prevalence, and children, among others. The keyword "children" stand out the most, like the one identified as an entity from all the terminologies. This discovery enshrines the global vulnerability of children to malnourishment, prevalence, and the associated risk factors. Malnutrition in children, therefore, proves to be a nagging global problem that requires continuous intervention. Additionally, the term "Mortality" consolidated the consequence of malnutrition. Especially in developing countries, mortality attributed to malnutrition remains problematic $[3,48]$. There is sufficient interconnectedness of the keywords that are significant to the experience of children's malnutrition-related issues. From this evidence, "diarrhea" 
and "birthweight" are some of the "risk factors" of malnutrition that may result in child "morbidity" and "mortality" incidences. Evidence has shown that diarrhea [49], and birth weight [48], are aggravators for child morbidity and mortality. Equally important is the occurrence of "body-mass index" and "body composition" as some of the measures of identifying the presence of malnutrition in patients.

Although children were prominent in the keyword analysis, maternal malnutrition equally appeared but less frequent. There are shreds of evidence of maternal undernutrition as impactful on newborns [50]. The analytical output of keywords suggests that nursing mothers or pregnant women are equally vulnerable to malnutrition and directly influence a child's health outcome. Thus, the nexus between maternal and child issues requires more studies to fast-track efforts to reduce morbidity risks [51].

Other significant keywords identified in the analysis offer insightful findings on some of the dynamics and associated risks of malnutrition. One of the occurrences and evidence of malnutrition is a severe shortage of "protein" and other energy "supplementation." This evidence supports the progress made in clinical studies exploring the potential effect of protein shortage on the human body [52]. The investigation of protein "deficiency" as a causative factor of malnutrition over the years, as evidenced in the keyword analysis, supports progress being made in research outputs. Thus, intervention for malnutrition patients should entail how supplements can be accessible, increase higher metabolism, and reduce malnutrition risk, especially in regions with the highest prevalence of malnutrition among vulnerable groups. The word "metabolism" appeared consistently in the keyword analysis. The repeated occurrence of metabolism may be closely associated with "protein" as a consistent keyword in literature, and the inability of the body to metabolize nutrients may cause excessive "weight-loss." This assertion may be a result of underlying diseases in the body that may affect protein metabolism. The clinical studies exploring malnutrition may also account for "rats" in the keyword analysis and "gene-expression" [53]. The cumulation of these keywords shows the extensive studies that have been conducted among "communities" and "developing countries" in an effort towards "subjective global assessment" of the "prevalence," to examine the "quality-of-life," and "health," "outcome" of malnutrition.

As initially indicated, the bulk of the top research on malnutrition is from the developed countries' contribution, asides in India and China who have both the characteristics of developed and developing countries. Sub-Saharan Africa did not make the top ten contributing authorship in malnutrition publications based on the WoS database search. In line with this recurring evidence, Sub-Saharan Africa and other developing nations across Asia, South America, and the Pacific are behind in global contributors in malnutrition research in the Web of Science. Concurrently, the lack of research, data, and contribution may hamper sustainable development goals, especially in sub-Saharan Africa [54]. Based on the assessment of the most influential publishing journals on malnutrition, the American and European journals remain top of the hierarchy. The first two are the American Journal of Clinical Nutrition and the British Journal of Nutrition.

In the combination of productive authors and the institution of affiliation, the network analysis revealed that Fris Henrik, Kerac Marko, Berkley Marko, Trehan Indi, and Guerrant
Richard has a minimum of 5 publication on malnutrition. Simultaneously, the University of London and Nutrition dietetics is the most prominent organization in research and focus. Represented in this cohort of the distinct organization are three organizations; Universidade De Sao Paulo (Brazil) and institute national de la Sante et de la recherché Medicale Inserm (France) and Cornell University (Canada) that are nonAmerican and Britain Institutions. Reverting to the initial evidence that the bulk of the current global malnutrition is prevalent in developing countries, it is safe to assume a shortage of developing country's organizational representation supporting publications addressing malnutrition in the Web of Science. A closer look at the research focus on malnutrition in the top contributing organization suggests that malnutrition's social determinant may have been overlooked as most research focus on pediatric, tropical, and clinical medicine.

The most prominent funders of malnutrition-related publications are nested in the United States, United Kingdom, and Brazil. Although Bill and Melinda Gates foundations are private donors, the NGO location is in the United States. Not to overstretch this, non-representation of developing countries in funding and over dependency may slow the global progress on lessening malnutrition.

Lastly, the rationale for citations of malnutrition publication is evidenced in the year of publication. Early studies created a template and made a direction for recent researches. Similarly, the number of authors was significantly correlated with the number of citations garnered by a malnutrition article. The journal h_index appears to be a significant determinant of if an author is going to cite an article. The h_index and a journal impact factor represent a vital indication of journal quality, and subsequently, authors tend to cite from such empirical evidence. Like the impact factor, the number of countries contributing and institutions directly correlated with malnutrition publication citations.

The implication of this research evidence accentuates the need to re-strategize and refocus some of the identified research patterns that have gained prominence over the last century in the WoS. At this junction, it is pertinent to eliminate various forms of the political debacle that may cloud intervention and policy framework to eliminate global malnutrition and use the same global political harmony to reduce the global prevalence of malnutrition [55]. In particular, the developing countries are in dire shortage of authorship, organization, publishing journals, and country representation on the web of science. Thus, a concerted effort should be made to create an enabling environment for authors, institutions, and journals from developing countries to thrive. If this method is adopted, the result is to accelerate the reduction of malnutrition in developing countries.

Similarly, as children are the most illustrious term in most of the WoS publications, it is essential to acknowledge that they are endangered and vulnerable groups. Therefore, an allinclusive global action must be intensified to eradicate malnutrition among them. The same goes for the population suffering from underlying ailments, the aging population, and hospital patients caught in the web of malnutrition. Lastly, it is also pertinent for developing countries to generate funds for malnutrition research to increase and encourage researchers in the regions.

This current research's novelty is the first bibliometric analysis on malnutrition as a wholesome topic (original article 
and review papers). However, the limitations must be considered when adopting the study research findings. We only used the WoS database to obtain released publications spanning over a century. Equally important, we excluded other types of documents such as book chapters, editorial materials, research notes, proceeding papers, book reviews, corrections, and conferences from the analysis. We did not include other databases for comparisons such as Scopus, PubMed, Google Scholar, and other non-English databases published. This procedure might affect the credibility of our results. Therefore, future research could consider using other databases and fill the research gaps.

In summary, there is a remarkable global effort towards solving the problem of malnutrition. The study shows the general increasing trend of research in malnutrition. There are substantiated evidence and progress on research centering on "care" and "support," "management," and "guidelines" to help people with malnutrition-related issues in the keyword analysis. These show that concerted global effort is in progress to manage malnutrition problems as a transition is made towards a malnutrition-free global environment. Also, the United States and Britain remain pivotal in bringing malnutrition prevalence to a halt, as identified in the current study. Overall, the developed countries have contributed a fair share of the authorship, organization, publishing journals in the Web of Science which acclimatized their effort in solving malnutrition-related problems. And lastly, the developing countries should be inculcated into the progress in malnutrition research. Therefore, funding should be made available in the region, especially sub-Saharan Africa, to facilitate more representation in the WoS.

Author contributions: All authors have sufficiently contributed to the study, and agreed with the results and conclusions.

Funding: The authors received no specific funding for this research

Declaration of interest: The author(s) declare no potential conflicting interest with respect to the research, authorship and/or publication of this article.

Acknowledgements: The author(s) acknowledges the support of the Organization of African Academic Doctors (OAAD) for enhancing research collaboration and innovation in Africa.

\section{REFERENCES}

1. Imran MIK, Inshafi MUA, Sheikh R, et al. Risk factors for acute respiratory infection in children younger than five years in Bangladesh. Public Health 2019; 173: 112-9. https://doi.org/10.1016/j.puhe.2019.05.011 PMid:31271965

2. Horton S, Steckel RH. Malnutrition Global economic losses attributable to malnutrition 1900- 2000 and projections to 2050. 2011; 37. Available at: https://www.copenhagen consensus.com/sites/default/files/malnutrition.pdf

3. Schaible UE, Kaufmann SHE. Malnutrition and Infection: Complex Mechanisms and Global Impacts. PLoS Med 2007; 4: e115. https://doi.org/10.1371/journal.pmed.0040115 PMid:17472433 PMCid:PMC1858706

4. Webb $P$, Stordalen $G A$, Singh $S$, et al. Hunger and malnutrition in the 21st century. Bmj 2018; k2238. https://doi.org/10.1136/bmj.k2238 PMid:29898884 PMCid: PMC5996965

5. Black RE, Victora CG, Walker SP, et al. Maternal and child undernutrition and overweight in low-income and middleincome countries. The Lancet. 2013; 382(9890): 427-51. https://doi.org/10.1016/S0140-6736(13)60937-X
6. Victora CG, Adair L, Fall C, et al. Maternal and child undernutrition: consequences for adult health and human capital. The Lancet. 2008; 371(9609): 340-57. https://doi.org/10.1016/S0140-6736(07)61692-4

7. Branca F. Malnutrition is a world health crisis. World Health Organization. Available at: https://www.who.int/news/ item/26-09-2019-malnutrition-is-a-world-health-crisis

8. The Global Nutrition Report. The Burden of Malnutrition. 2018. Available at: https://globalnutritionreport.org/ reports/global-nutrition-report-2018/

9. World Health Organization. - Malnutrition. Available at: https://www.who.int/health-

topics/malnutrition\#tab=tab_1

10. Saunders J, Smith T, Stroud M. Malnutrition and undernutrition. Medicine (United Kingdom). 2015. https://doi.org/10.1016/j.mpmed.2014.11.015

11. Pulgar IH, Campayo ES, Valero ML. Malnutrition. Med Spain. 2020; 13(14): 787-92. https://doi.org/10.1016/j.med.2020. 07.012

12. Tommy A, Musa TH, Kawuki J, et al. Parental Knowledge of Malnutrition as a Cause of Infant and Child Mortality Rate in Torbu Community, Sierra Leone. Int J Child Health Nutr. 2020; 9(2): 74-80. https://doi.org/10.6000/1929-4247.2020. 09.02.4

13. Singh S. Prevelence of Obesity among school children of low socio economic status is much lesser then malnutrition. Iors J Humanit Soc Sci. 2012; 3(5): 32-4. https://doi.org/10.9790/0837-0353234

14. Black RE, Allen LH, Bhutta ZA, et al. Maternal and child undernutrition: global and regional exposures and health consequences. The Lancet. 2008; 371(9608): 243-60. https://doi.org/10.1016/S0140-6736(07)61690-0

15. Gonzalez Navarrete WR. Understanding the Early Stages of Development of a Global Health Partnership. 2013. Available at: https://scholarcommons.sc.edu/etd/1366/

16. Stenvinkel $P$, Heimbürger $O$, Paultre $F$, et al. Strong association between malnutrition, inflammation, and atherosclerosis in chronic renal failure. Kidney Int. 1999; 55(5): 1899-911. https://doi.org/10.1046/j.1523-1755.1999. 00422.x PMid:10231453

17. Tayyem RF, Mrayyan MT. Assessing the Prevalence of Malnutrition in Chronic Kidney Disease Patients in Jordan. J Ren Nutr 2008; 18: 202-9. https://doi.org/10.1053/ j.jrn.2007.10.001 PMid:18267213

18. Luyckx VA, Brenner BM. Birth weight, malnutrition and kidney-associated outcomes-a global concern. Nat Rev Nephrol 2015; 11: 135-49. https://doi.org/10.1038/nrneph. 2014.251 PMid:25599618

19. Rubenstein LZ, Harker JO, Salvà A, et al. Screening for undernutrition in geriatric practice: Developing the ShortForm Mini-Nutritional Assessment. J Gerontol - Ser Biol Sci Med Sci. 2001; 56(6): M366-M372. https://doi.org/ 10.1093/gerona/56.6.M366 PMid:11382797

20. Tripathy S, Mishra JC, Dash SC. Critically ill elderly patients in a developing world-mortality and functional outcome at 1 year: A prospective single-center study. J Crit Care 2014; 29: 474.e7-474.e13. https://doi.org/10.1016/ j.jcrc.2014.01.007 PMid:24581949

21. Correia MITD, Hegazi RA, Higashiguchi T, et al. EvidenceBased Recommendations for 1Addressing Malnutrition in Health Care: An Updated Strategy From the feed M.E. Global Study Group. J Am Med Dir Assoc 2014; 15(8): 54450. https://doi.org/10.1016/j.jamda.2014.05.011 PMid: 24997720 
22. Steer B, Loeliger J, Edbrooke L, et al. Malnutrition Prevalence according to the GLIM Criteria in Head and Neck Cancer Patients Undergoing Cancer Treatment. Nutrients 2020; 12(11): 3493. https://doi.org/10.3390/nu12113493 PMid:33203000 PMCid:PMC7697929

23. Karampelas K. Trends on Science Education Research Topics in Education Journals. Eur J Sci Math Educ 2021; 9(1): 1-12. https://doi.org/10.30935/scimath/9556

24. Rizvi S, Kisa A, Younis M. death-dying-and-end-of-life-carein-the-us-and-the-netherlands-a-scoping-review. Eur J Environ Public Health 2020; 4(2): em0042. https://doi.org/10.29333/ejeph/8218

25. Sine H. Anxiety, Depression and Sleep Disorders during Coronavirus Disease: A Systematic Review. Eur J Bas Med Sci 2020; 10(1): 11-26. https://doi.org/10.21601/ejbms/9251

26. Ha CT, Thao TTP, Trung NT, et al. A Bibliometric Review of Research on STEM Education in ASEAN: Science Mapping the Literature in Scopus Database, 2000 to 2019. Eurasia J Math Sci Technol Educ 2020; 16(10): em1889. https://doi.org/10.29333/ejmste/8500

27. Gallegos M, Cervigni M, Consoli AJ, et al. COVID-19 in Latin America: A Bibliometric Analysis of Scientific Publications in Health. Electron J Gen Med 2020; 17(6): em261. https://doi.org/10.29333/ejgm/8460

28. Hirsch JE. An index to quantify an individual's scientific research output. Proc Natl Acad Sci USA. 2005; 102(46): 16569-72. https://doi.org/10.1073/pnas.0507655102 PMid:16275915 PMCid:PMC1283832

29. Van Eck NJ, Waltman L. Software survey: Vosviewer, a computer program for bibliometric mapping. Scientometrics. 2010; 84: 523-38. https://doi.org/10.1007/ s11192-009-0146-3 PMid:20585380 PMCid:PMC2883932

30. Aria M, Cuccurullo C. bibliometrix: An R-tool for comprehensive science mapping analysis. J Informetr. 2017; 11(4): 959-75. https://doi.org/10.1016/j.joi.2017.08. 007

31. Motulsky H. GraphPad Prism5.0 Statistics Guide. Clases.

32. Bhutta ZA, Ahmed T, Black RE, et al. What works? Interventions for maternal and child undernutrition and survival. The Lancet. 2008; 371(9610): 417-40. https://doi.org/10.1016/S0140-6736(07)61693-6

33. Winick $M$, Noble A. Cellular response in rats during malnutrition at various ages. J Nutr. 1966; 89(3): 300-6. https://doi.org/10.1093/jn/89.3.300 PMid:5913937

34. Correia MITD, Waitzberg DL. The impact of malnutrition on morbidity, mortality, length of hospital stay and costs evaluated through a multivariate model analysis. Clin Nutr. 2003; 22(3): 235-9. https://doi.org/10.1016/S02615614(02)00215-7

35. McWhirter JP. Incidence and recognition of malnutrition in hospital. Clinical Nutrition. 1994; 13(4): 267-8. https://doi.org/10.1016/0261-5614(94)90087-6

36. Bistrian BR, Blackburn GL, Vitale J, et al. Prevalence of Malnutrition in General Medical Patients. J Am Med Assoc. 1976; 235(15): 1567-70. https://doi.org/10.1001/ jama.1976.03260410023017 PMid:814258

37. United Nations. The Millennium Development Goal Report. Addendum. Available at: https://unstats.un.org/unsd/mdg /Resources/Static/Products/Progress2014/Goal4_Addend um.pdf
38. Haddad L, Achadi E, Bendech MA, et al. The Global Nutrition Report 2014: Actions and Accountability to Accelerate the World's Progress on Nutrition. J Nutr 2015; 145(4): 663-71. https://doi.org/10.3945/jn.114.206078 PMid:25740908 PMCid:PMC5129664

39. United Nation. The Millennium Development Goals Report 2015. Available at: https://www.un.org/millenniumgoals/ 2015_MDG_Report/pdf/MDG\%202015\%20rev\%20(July\%2 01).pdf

40. De Onis M, Frongillo EA. Is malnutrition declining? An analysis of changes in levels of child malnutrition since 1980. Bull World Health Organ 2000; 78(10): 1222-33. https://www.ncbi.nlm.nih.gov/pmc/articles/PMC2560621

41. UN. Take Action for the Sustainable Development Goals. United Nations Sustainable Development. 2015. Available at: https://www.un.org/sustainabledevelopment/sustain able-development-goals/ (Accessed: 8 March 2021).

42. Simkhada PP, Baral YR, van Teijlingen ER. Health and Medical Research in Nepal: A Bibliometric Review. Asia Pac J Public Health 2010; 22(4): 492-500. https://doi.org/ 10.1177/1010539510371020 PMid:20462852

43. Suzan V, Unal D. Comparison of attention for malnutrition research on social media versus academia: Altmetric score analysis. Nutrition 2021; 82: 111060. https://doi.org/10.1016/j.nut.2020.111060 PMid:33340854

44. Alamri SH. Geriatric Research in Saudi Arabia: A Bibliometric Analysis. J Adv Med Med Res 2020; 31(12): 1-9. https://doi.org/10.9734/jammr/2019/v31i1230336

45. Lee YJ, Park BS, Park JH, et al. Top 100 Cited Articles on Peritoneal Dialysis: A Bibliometric Analysis. Open Urol Nephrol J 2020; 13: 39-47. https://doi.org/10.2174/ $1874303 \times 02013010039$

46. Kramer CV, Allen S. Malnutrition in developing countries. Paediatr Child Health 2015; 25(9): 422-7. https://doi.org/ 10.1016/j.paed.2015.04.002

47. Kalu RE, Etim KD. Factors associated with malnutrition among underfive children in developing countries: A review. Glob J Pure Appl Sci 2018; 24(1): 69. https://doi.org/10.4314/gjpas.v24i1.8

48. Page A-L, de Rekeneire N, Sayadi S, et al. Infections in Children Admitted with Complicated Severe Acute Malnutrition in Niger. PLoS One 2013; 8(7): e68699. https://doi.org/10.1371/journal.pone.0068699 PMid:23874731 PMCid:PMC3714292

49. Ganguly E, Sharma PK, Bunker Ch. Prevalence and Risk Factors of Diarrhea Morbidity among Under-Five Children In India: A Systematic Review And Meta-Analysis. Indian J Child Health 2015; 2(4): 152-60. https://doi.org/10.32677/ IJCH.2015.v02.i04.004 PMid:26925453 PMCid:PMC4764679

50. Rossi C, Cicalini I, Rizzo C, et al. A False-Positive Case of Methylmalonic Aciduria by Tandem Mass Spectrometry Newborn Screening Dependent on Maternal Malnutrition in Pregnancy. Int J Environ Res Public Health 2020; 17(10): 3601. https://doi.org/10.3390/ijerph17103601 PMid: 32443888 PMCid:PMC7277087

51. Akintunde TY, Chen S, Ibrahim E, et al. Maternal Self-rated Capability Status and Its Association with Under-Five Children Morbidity. J Prim Care Community Health 2021; 12: 21501327211002104. https://doi.org/10.1177/ 21501327211002102 PMid:33715503 PMCid:PMC7968025

52. Semba RD. The Rise and Fall of Protein Malnutrition in Global Health. Ann Nutr Metab 2016; 69(2): 79-88. https://doi.org/10.1159/000449175 PMid:27576545 PMCid: PMC5114156 
53. Gombar FM, Ramos CF. Perinatal malnutrition programs gene expression of leptin receptors isoforms in testis and prostate of adult rats. Regul Pept 2013; 184: 115-20. https:// doi.org/10.1016/j.regpep.2013.03.009 PMid:23499808

54. Juju D, Baffoe G, Dam Lam R, et al. Sustainability Challenges in Sub-Saharan Africa in the Context of the Sustainable Development Goals (SDGs). In: Gasparatos A, Ahmed A, Naidoo M, et al. (eds) Sustainability Challenges in Sub-Saharan Africa I. Singapore: Springer Singapore, pp. 350. https://doi.org/10.1007/978-981-15-4458-3_1
55. Gillespie S, Haddad L, Mannar V, et al. The politics of reducing malnutrition: building commitment and accelerating progress. The Lancet 2013; 382(9891): 552569. https://doi.org/10.1016/S0140-6736(13)60842-9 